\title{
BODIES IN DISSENT
}





\section{BODIES IN DISSENT}

Spectacular Performances of Race and Freedom, 1850-1910

\section{Daphne A. Brooks}

Duke University Press Durham and London 2006 
(C) 2006 Duke University Press

All rights reserved

Printed in the United States

of America on acid-free paper $\infty$

Designed by Amy Ruth Buchanan

Typeset in Minion by Keystone

Typesetting, Inc.

Library of Congress Cataloging-in-

Publication Data and republication

acknowledgments appear on the last

printed page of this book.

Duke University Press gratefully

acknowledges the support of

Princeton University, which

provided funds toward the

production of this book. 
For

Juanita Kathryn Watson Brooks

and in memory of

Nathaniel Hawthorne Brooks, Sr. 
